\title{
The Contemporary Changes and Uses of Adat in Gayo Society, Indonesia
}

\author{
A. Arfiansyah \\ Leiden University, Netherlands \\ corresponding author: a.arfiansyah@hum.leidenuniv.nl \\ Submitted: 21-4-21021; Accepted: 27-4-2021 \\ DOI: $10.31291 /$ hn.v10i1.620
}

\begin{abstract}
By employing ethnographic methods, this research seeks to provide answer on what has changed in Gayo adat law, particularly after the Aceh government formalized adat law and adat institution? How is the adat being utilized by the Gayonese? What does adat serve for? This paper updates the discourse on Gayonese adat that has been extensively studied by John R. Bowen. Unlike Bowen's study that focused on adat family law, this article explores both adat family law and adat penal law to observe the development of adat comprehensively. This research was conducted in Gayo society inhabiting both Central Aceh and Bener Meriah district, and it observes a new development of adat that is different from Bowen's observation. It argues that Adat family law has transformed from being separated from Islam and state (as observed by Bowen) into being integral to the implementation of Islamic teachings in the community. Adat is currently being used to maintain the harmony and unity of kinship. For that purpose, Gayonese makes independent Islamic legal reasonings where conclusion is framed within the context of Islam, although at a glance it appears deviance from the standard Islamic law. Meanwhile, adat penal law which is recently revived by the state is functioned for different purposes by different actors. For activists, adat is important for social transformation, while for the state, adat is used to support legal enforcement at the village.
\end{abstract}

Keyword: Gayonese; adat; contested field; social transformation

HERITAGE OF NUSANTARA:

INTERNATIONAL JOURNAL OF RELIGIOUS LITERATURE AND HERITAGE 


\begin{abstract}
Abstrak
Dengan menggunakan metode etnografi, penelitian ini bertujuan menjawab pertanyaan tentang apa yang telah berubah pada adat terutama setelah Pemerintah Aceh menformalkan hukum dan institusi adat, bagaimana adat digunakan oleh masyarakat Gayo, dan apa yang bisa diberikan oleh adat. Artikel ini memperbaharui dikursus tentang adat masyarakat Gayo yang telah dikaji secara ekstensif oleh John R. Bowen. Berbeda dengan Bowen yang mempelajari hukum keluarga (adat), penelitian ini mempelajari hukum keluarga adat dan hukum pidana adat untuk melihat perkembangan adat secara lebih komprehensif. Penelitian ini dilakukan pada masyarakat Gayo yang mendiami Kabupaten Aceh Tengah dan Bener Meriah dan melihat perkembangan yang berbeda dari yang telah Bowen perhatikan. Artikel ini berpandangan bahwa hukum adat untuk keluarga telah bertransformasi dari yang sebelumnya terpisah dari ajaran Islam dan negara menjadi bagian tak terpisahkan dari praktik penerapan ajaran Islam dalam masyarakat. Hukum Adat untuk keluarga sekarang ini berfungsi mempertahankan keharmonisan dan kesatuan keluarga besar. Untuk tujuan itu, Orang Gayo kerap melakukan penalaran hukum Islam secara independen yang kesimpulannya dibingkai dalam kontek ajaran Islam yang lebih luas, yang bisa sekilas terlihat menyimpang dari standar hukum Islam. Sedangkan, Hukum pidana Adat, yang baru saja diperkenalkan kembali oleh pemerintah, digunakan untuk tujuan berbeda oleh aktor yang berbeda. Bagi aktivis, adat penting digunakan untuk transformasi sosial. Sementara untuk negara, adat penting untuk mendukung penegakan hukum di desa.
\end{abstract}

Kata Kunci: Gayo; adat; kontestasi; transformasi sosial

\title{
Introduction
}

Adat has become one of central issues for state-building project of Indonesia in post New Order administration. Following the shift of political orientation from authoritarianism to democracy and the influence of International Convention on indigenous community, Indonesian government revised law on regional government that refined the position of adat and indigenous community in Indonesia. Both positions can be seen at two levels in the Regional Law of 2004: the first is village autonomy and the second is district autonomy (Bedner \& Huis,

36| VOL. 10 NO. 1 JUNE 2021 
2008, pp. 172-176). Adat then has become politically crucial for long ignored indigenous communities to fight for their indigeneity (Muur et al., 2019), land rights (Bedner \& Arizona, 2019; Muur, 2018), against the dominant religious and cultural groups $(\mathrm{Erb}, 2007)$ that concretes the construction of "insider" and "outsider" in some places in Indonesia (Bouchier, 2007). This development, as observed by Bedner and Arizona, shows the fast changing use of adat from cultural and spiritual unity and uniqueness of Indonesia to something local with which to resist the national and regional government (Bedner \& Arizona, 2019, p. 417).

Aside of the political and local meanings of adat in the post New Order era, adat penal law is utilized for legal purposes of the state. In this situation, adat is not only associated with local, but also national and regional interests to handle the limit of the state in presenting equilibrium and order in the society. At the national level, central government has been struggling to administer adat penal law to be part of national penal bill (Aktual, 2015; Aziz, 2016). In 2008, at regional level, Aceh government issued two regional regulations (locally called Qanun) 9/2008 on the Supervision the Life of Adat and Adat Istiadat (customs) and Qanun 10/2008 on Adat Institution recognizing adat law and its institutions to be part of state legal system. The latest Qanun suggests the codification of adat to be the village regulation. The provisions of the Qanun are enforced by the village apparatus who are now agent of the state in the village and are allowed to handle minor crimes taking place at the village. Village apparatus in Gayo community, inhabiting the central part of Aceh province, enjoy the same development. 
Another transformation and changing uses of adat law relates to familial issues. Unlike the adat penal law, adat relating to family issues is not administered by the state although it has been subject of the state legal project since the post independent of Indonesia (Bowen, 1988, 2000). Since then, Gayo adat has transformed from what Bowen observed as being associated with maintaining link to ancestry and center at the village (Bowen, 2003, p. 44) to being associated to maintaining kinship, where adat familial law is also centered.

This article examines the contemporary use of adat by observing the changing and the continuity of adat law both in family and penal law aspects in the Gayonese society inhabiting Central Aceh and Bener Meriah District of Aceh Province. This paper also serves as an update to John R. Bowen's studies on Gayo Adat. It focuses on what has changed in Gayo adat law since in the last 15 years, how adat is used by Gayonese, and what adat serves for.

\section{Method}

Field work was conducted in mid of 2014 to mid of 2015 in both Central Aceh and Bener Meriah districts which are home to Gayonese ethnic group. I did vast number of interviews in both districts with adat elites, villagers, government official, and women activists. Case studies presented in this essay were collected ethnographically. Achyar's kinship, which is the first case studied here, represents the development of adat family law in Gayonese society. Second case study was collected from my involvement in the Hasanah and Yusdarita's activities in Bener Meriah district. Both are prominent women activists in the area. They assisted me to connect with other activists and government officials of Bener Meriah. 
The collected data is presented in historical order and is divided into three sections. Section one discusses briefly the discourse of adat law and its classification. For this historical part, I rely my information on Bowen's works and local publications. Section two examines the development and the changing use of adat family law by presenting a detail case of adat legal practice in Ahyar's kin. Section three portrays the development of adat penal law. This section presents the revival of adat penal law motored by the multi-organization in post conflict and Tsunami of Aceh. Subsequently, it also presents the use of adat law by activists at village level by presenting a case from Rembele village of Bener Meriah district.

Having observed the development of adat from colonial to current development, this article argues that Adat is continuously (re)defined, (re)constructed, (re)organized to set a new standard of social life, a new way of looking and observing communal actions and others, and is a medium to maintain internal family stability and continuity. It is a contested field for those who seeks to promote community to a certain development. Therefore, adat has been transformed following the development of one society and the influence of external forces. Both internal and external forces are mixed into adat. Following Benda Beckman's argument on the Minangkabau' adat as a hybrid law (F \& K Benda-Beckmann, 2013, pp. 421-422), the Gayonese adat also hybridizes all external norm and turn them into adat. This hybrid adat law consists of many different norms stemming from Islam, secular, and others.

The hybrid adat law and the influence of other various external forces produce a new practice and use of adat. Adat dealing with family issues 
The Contemporary Changes ...

is now crucial to maintain unity of a kinship. In doing so, people produce independent legal reasonings framed within the context of Islam to support their interests in the kinship unity. Meanwhile adat penal law has been revived by the state to support the legal enforcement and to provide access to justice for the community. For some villages, adat is important to improve communal life. While for other villages, adat is developed to the reverse situation.

\section{Result and Discussion}

\section{Islamizing adat and Early Reform of Adat Family Law}

This section discusses the situation during the Dutch colonialism, in which adat became a contested arena between the traditionalist and modernist Muslims in their mission to lead Gayonese to the proper way of being a Muslim. Shown in this section that adat is important for these groups in two different ways. For the traditionalists, the construction of adat has to be sustained, filled and nuanced with Islamic teachings. Meanwhile, for the modernists carrying religious purification campaign, adat has to be completely replaced with Islamic norms and traditions.

The contextualization and vernacularization of Islamic norms into adat have intensified following the increase in multi-cultural interaction between local and immigrant brought by Dutch to the region since their first arrival in 1902. When they eventually controlled the Gayo, they developed Gayo highland for the Dutch agriculture project. They introduced various horticultural crops, tea and Arabica coffee. They constructed a road that connected the central part to the northern coast of Aceh to bring the crops from Gayo to outside world. They brought large numbers of Javanese and Chinese for construction and plantation. Many also came by their own, mainly the Minangkabau, for trading as

40 | VOL. 10 NO. 1 JUNE 2021 
well as for spreading Islamic reform and purification (Bowen, 1991, pp. 76-79).

The Dutch built schools to promote colonial administration in the area. In the early of 1910s, they built two volkschool of three-year program. By 1940, the Dutch already built another eleven volkschools (Bowen, 1991, p. 94; PaEni, 2003, p. 187). They brought Tapanuli and Minangkabau people, who were in touch with Muhammadiyah organization - a Muslim reformist organization founded in Yogyakarta in 1920- to work at schools (Bowen, 1991, p. 97).

The Dutch sent a small number of men to be trained at the Dutch-funded schools in Pematang Siantar of North Sumatra and Koetaradja (Banda Aceh today) for a higher level of education. There, many Gayonese took part in nationalist movements. Once they returned, aside from replacing immigrant teachers at the schools (PaEni, 2003, p. 187), they also troubled the Dutch with their nationalism. The most popular figure of these groups was Abdul Wahad who later became the first regent of the area in the post-independence of Indonesia (Bowen, 1991, p. 94).

The influx of immigrants that led to cultural and knowledge exchanges attracted many Gayonese to go to other places in the East Indies to pursue education. Among them were Ahmad Damanhuri (died 1942) and Abdul Jalil (died 1976) who created their own "religious circles" that intensified the islamization in Gayo. Damanhuri dan Abdul Jalil led an Islamic movement of kaum tue (old group) and kaum mude (young group) that opposed to each other. ${ }^{\mathrm{i}}$

One of the major inventions of this period was the classification of adat. There were five classifications of adat; Adat-tullah, Adat al- 
Muhakamah, Adat al-Muthmainnah, Adat al-Jahiliyah and Resam. ${ }^{\mathrm{ii}}$ This classification was formulated to separate non-Islamic practices from the adat. According to Pinan, who served in Giyugun armed force under the Japanese, the classification appeared for the first time during the Dutch colonial (Pinan, 1997). Apparently, it appeared after 1930 during the increase of islamization of adat. It was not clear of who made the classification. I assume that, looking at its tolerance toward the adat, it should be the traditionalist group who contributed to the classification. This classification was the foundation for further islamization in Gayo.

\section{1) Changes in adat Family law}

In the post Japanese colonial time, the islamization went to a greater extent, transforming many aspects of adat in family matters. The transformation was eased by the oppressiveness of the Japanese toward the locals. In the beginning, the Japanese was seen as a liberator from the Dutch. However, as the time went by, the Japanese turned to be more oppressive. They prohibited Gayonese from practicing their adat and religion (Bowen, 1991, pp. 102-105). This period, according to Pinan, was a huge decline of adat (Pinan 2003, 15-19).

However, some considered the absence of adat from everyday life during the Japanese colonialism as a great momentum to create a new norm; Islamic and nationalism norms. Muslims scholars, both tue and mude groups, and nationalist figures then shared a common vision of creating "modern Gayo", in which Islam was at the central idea of modernity. Although they had different ideas about this "modernity," they were on the same page about the need to replace adat with Islamic traditions. In a meeting held in early 1946, Abdul Jalil called for the rejection of adat in its entirety. It had to be replaced by Islam. In the 
same year, the nationalist group and religious teachers viewed adat as pro-Dutch domain lord and religious backwardness. They changed gradually some adat aspect in family matters such as in marriage, dowry, and inheritance practices. Former system of marriage payments that had been tied to the rank of bride's father was also replaced with Islamic payment of mahr. Former marriage payment made by parents of bride and groom to their respective village rulers was also prohibited. Some local elites' officials tried to permit marriage of the same clan, which was previously prohibited by the adat (Bowen, 1991, p. 111).

This radical islamization of adat was not fully accepted by the community. As a protest, some of the ruler's kin groups left the villages. Their action led to the defection of villages members which caused depopulation and fraction in villages. Saleh Adry, the younger brother of Tgk. Damanhuri and later became the second most prominent figure in Ulama revolt in Gayo after Ilyas Leube was assigned as a spokesman for the new district increased the tension between Islam and adat. $\mathrm{He}$ traveled across the district proclaiming the "end of adat". Many villages reacted angrily to his speech saying “...so we are to be like a goat?" implying that they would be like an animal without the guidance of adat, while the alternative from what the Ulama campaigned as Islamic tradition replacing the adat has not been found yet (Bowen, 1991, p. 112).

\section{2) The court contribution to the adat transformation}

Among the main subjects of islamization was the inheritance division. In the early establishment of the state religious and civil courts, judge contributed very much in transforming adat family law aspects. Judges 
of the religious court of this period were mostly Gayo origin. They were familiar with adat, social and political dynamics as well as with the demand of local Muslim scholars for the creation of a new society based on Islam. However, as it was an early set up period, they faced a lack of authority, organization structure and facilities. Lacking in these aspects complicated the judge to reaffirm the division based on either adat or Islamic law. Judges were also worried for immediate political consequence from the religious movement of Darul Islam at that time, led by Ilyas Leube and Saleh Adry, if they did not bring Islamic law into practices. Applying Islamic law also required great courage to resist the opposition from the Gayonese, who were their legal subject. The judges then avoided framing the case of "Islam versus adat". Instead, they brought the parties to do consensus outside the court in a familial manner, in which reasonings based on adat and Islamic law were brought into play mediated by judges, Muslim scholars and adat leaders. The consensus involving these actors often concluded the inheritance cases by equal shares between brother and sister. Until the 1970s, the judge continued practicing the property division in such way following the logic of the new invented adat. Even though a decision through consensus was brought to either the religious court or a civil court to be re-divided based on Islamic law, judge of both courts avoided invalidating past property division (Bowen, 1988, p. 281, 1998, 2000, pp. 107-112). The new division practice gradually changed the old one in which a daughter could not claim any portion from inheritance. Later it became standard for Gayonese in dividing inheritance, which I assume, was not observed by Bowen.

During the early setup of the courts, the judges of religious court introduced Poroh (my informants pronounce this as "poh roh", 
accumulated wealth earned during the marriage that must be divided equally after divorce) and it was supported by Muslim scholars. Following the economic development in Gayo where the coffee plantation was increasing and was not tied to the ancestral land, the court considered property obtained or improved during the marriage to be earned wealth. In 1959, judges no longer recognized a claim to the earned wealth based on the marriage states or village affiliation (Bowen, 1988, pp. 281-282).

This was quite a novel development. Before the establishment of the courts and the increasing of the coffee plantation, a divorced woman had no rights over earned wealth. At that time, the main shared labor of husband and wife was a rice field. It was affiliated to the village and tied to ancestry. The affiliation to the village was contingent on the continuity of the kind of marriage whether patrilocal or matrilocal. This adat law was replaced following the growing of coffee estate, in which a couple commonly had to clear land for the coffee plantation that was quite far from the village. This new economical source was the judge's reflection to introduce poroh (Bowen, 1988, pp. 278, 282-283).

Judges also promoted bilateral inheritance, putting aside many early property distributions. According to some Gayonese legal scholars, like Prof. Alyasa Abubakar and Jamhuri who are members of the State Islamic University of Ar-Raniry of Banda Aceh, argued that a woman married patrilocally would not receive any inheritance, because she received the bride's goods and livestock like a horse or water buffalo, supporting her life in the new dwelling. The livestock was more expensive than the land that could be obtained freely at the time. In addition, as Bowen explains, traditional cultivated land was mainly rice HERITAGE OF NUSANTARA: 
field that tied to ancestry which blocked the rights of the daughter married patrilocally to claim inheritance. This situation allowed the eldest brother to control the inherited land who, based on the local kinship system, would be in charge for the family affairs after the death of the father. Judges of both religious and civil court gradually eliminated passing wealth based on this pattern of marriage and affiliation (Bowen, 1988, pp. 282-284).

This islamization since the early coming of the Dutch until present has led many Gayonese today to consider their adat as an actualization of Islamic teachings. Many local publications, such as Mahmud Ibrahim's three-volume books on Shari'a and Adat (Ibrahim \& Pinan, 2002, 2005, 2010), seminar and talk on Gayo adat today speak about the contextualization and articulation of Islamic teachings in the adat.

The changing practice of inheritance division was also driven by the state policy on land management. In 1960, Indonesia government promoted the land ownership and certification through Agrarian Law $5 / 1960$. Since then, the land gradually lost its tie to village and ancestry. Land was then owned by individual, traditional community (adat land) or the state. Moreover, the coffee plantation, untied from ancestry land, later became the main property of large number of Gayonese. The land ownership gradually changed the objective of inheritance practice in Gayo adat from previously aiming at maintaining link to ancestry, as described by Bowen, to aiming at maintaining kinship. This change started after the invention of new labor (the coffee plantation) that led to local migration for clearing forestry area for a new coffee plantations and the introduction of the land ownership by the state.

The following section of case study provides an empirical evidence based on detailed description suggesting the changes of adat family law 46| VOL. 10 NO. 1 JUNE 2021 
and the influence of islamization on inheritance division. The case presents an adat legal practice within Achyar's kin and its function to maintain harmony of the kinship. For that purpose, Achyar did not follow the standard Islamic law on inheritance; he decided dividing the inheritance equally between brother and sister instead. The division was framed within the Islamic context. This development, I observe, was the outcome of all situations presented in previous discussion (informal assistant of the judges in familial consensus during the early setup of the court, the state policy on the land ownership, and development of coffee plantation, a new economic resource that was untied to ancestry).

\section{3) Adat family law for kinship unity and harmony}

In Gayo, as Bowen describes, the oldest brother would control all family's property after of the death of the father. Such a central figure playing the father's role makes oldest brother become decisive in controlling the common property in the Gayonese kinship system. Achyar, living in Takengen of Central Aceh district, played such role. Achyar's role was decisive in maintaining the tie of three generations of his extended family: his generation, son, and grandson. This role obliged him to maintain stability and present general harmony among them as a mean to maintain the kin tie.

Achyar's father passed away in 1994 from the stroke. He left 37,482.5 meter2 of the coffee plantation in Bener Meriah district. Several months after the lost, Achyar suggested his siblings to allow Marini, the youngest sister who took care of their father and stopped her bachelor degree for the father care, to take $6,750 \mathrm{~m} 2$ of the coffee plantation. Achyar conditioned that if at the time of land division in the future her 
siblings got more than she got, her part would not be adjusted to the latest division. It was a fixed measure. Achyar contemplated that it was supposed to be the son responsibility to take care of their father during the sick. Unfortunately, everyone was limited by their business as breadwinners and state officials. Marini deserved to get the land to support herself as she intentionally dropped her chance to get diploma as her siblings did.

Another sibling, Amrun, approached his mother behind the back of all his siblings. He asked the same partition of land as Marini got. He argued that he supported the life of the parent by taking care the entire coffee plantation. According to Achyar, their mother was most probably silent, instead of answering his request. Amrun understood the silence as an agreement. He then took a portion of the estate as large as Marini got. And none of his siblings complained.

In 2008, In the presence of their mother and witnessed by Marini and Amrun, Achyar's led the division of the plantation equally between brother and sister. He argued that they were all the children of their parents who did not differentiate son from daughter during their life time. Although he was fully aware of Islamic law formula suggesting the son gets more portion than the daughter (2:1). Achyar was supported by Hidayat Syah, his younger brother and an imam of Jongok Bathin village who was trained in Islamic studies under the instruction of his uncle, Saleh Adry mentioned briefly above. Hidayat Syah reasoned that Islam does not suggest partition of group. It was the mission of Islam to unite humankind, maintain harmony and love and not to make them in harm, hatred and separated. Their mother chose to be silent, leaving her children to find justice among them. 
All siblings agreed with Achyar's argument and Hidayatsyah's reasonings. They then decided equal division between son and daughter in random draw method. According to Hidayat Syah, any number that they picked was predestination from Allah. If one attained the poor or smaller part, it was a destiny that had to be sincerely accepted. It was decided by Allah. The agreement shared the land roughly $3.426 \mathrm{~m} 2$ each. Marini and Amrun got larger share for $6.750 \mathrm{~m} 2$ that they got before the division process.

According to Hidayat Syah, the standard division in Islamic law is too rigid and does not consider non-material aspects. It is the last resolution to take would they face a deadlock. He reasoned that:

\begin{abstract}
"my sister quitted university and spent her life to take care of our father and mother, none of us had paid more attention more than she did. Law is very fixed. We do not find a solution in the law to give her what she deserved. We might take the law and give her our (male siblings) parts after the division. However, some might be reluctant to do that and could cause bitterness if only one or two among the male siblings donate their part to her. She could be displeased to those who do not donate....the best way to avoid this is to turn down the law and take consensus (musyawarah) among us."
\end{abstract}

According to Achyar dan Hidayat Syah, although there is a fixed formula in Islamic law for inheritance division, a consensus is the most basic legal procedure before looking for other options in Islamic law. Achyar then quotes a verse of the Quran to support his argument:

\footnotetext{
"And those who have responded to their Lord and established prayer and whose affair is [determined by] consultation among themselves, and from what We have provided them, they spend [Quran 42:38]."
}

The verse provides the source for their legal reasoning to take consensus or "consultation among themselves", as Achyar referred to the verse as the basis for the equal division. By doing so, they skip the fixed formula 
for its rigidness. Moreover, according to Achyar and Hidayat Syah, the non-material aspect is more important for them than the material (land) left by their father. This aspect is not considered by Islamic law. Their father treated them equally that they do not find any reason to differentiate brother from sister. Such equal division is quite common in Central Aceh and Bener Meriah today. Sirajuddin, Head of Adat Council of Bener Meriah says that he used to be acting as witnesses in many familial consensuses concluding the equal sharing.

Islamic discourses provide vast argument to support Achyar and Hidayat Syah practice. Muhammad Shahrur, for example, said that the fundamental principle in Islamic science of division is justice and equality. The application of these principles may differ from one community to another depending on the sense of justice and freedom of the community (Shahrur, 2004, p. 336). Alyasa Abubakar, a professor of Islamic Jurisprudence at the State Islamic University of Ar-Raniry and Gayonese himself, gave the same thought when I consulted with about the Achyar's case. He said that the division based on the Islamic law is not necessarily taken as it only provides the least justice that everyone has to take as a final solution.

Achyar's case also suggests that a Muslim often encounters with conflicting situations. On the one hand, they always try to be a good Muslim by referring their practice to Islamic texts produced by ulama. On the other hand, however, they have to deal with situations that are not discussed in any circulated text around them. Achyar attempted to negotiate and establish reasons that are still framed within Islamic context to accommodate his interest in the kinship unity. Achyar and his sibling do not think that they are being deviant from Islamic teachings, nor practicing non-Islamic law. They even believe that they are 50| VOL. 10 NO. 1 JUNE 2021 
practicing part of the very basic forms and most fundamental teachings of Islam namely unity and harmony, that could be served through delivering the sense of justice and equality among them.

\section{B. The Revival of Adat: Adat Penal Law}

In the preceding section, we have seen the transformation of adat family law. The following section discusses the re-emergence, transformation and codification of adat penal law. It is important to note that before the inclusion of adat institution as a part of the state, Gayonese's adat penal law has been gradually abolished by state promoting the centralism of the state legal system. Adat penal law reclaimed its significance since the Aceh government recognized adat institutionally in 2008. Since then, adat penal law has become a contested field of those who seek to transform the community.

The development of adat penal law in Aceh province commenced in the post-conflict and disaster of Aceh province, after Indonesia government granted Aceh province a special autonomy in cultural aspects, in addition to religious and educational aspects. With the grant, Aceh government revived traditional structure of village organizations and converted them into formal village institutions. Today, adat institutions are the village formal institutions and their actors are the state agents at the village. The government also promoted the codification of adat law to be village regulation, locally known as Qanun Kampong.

At the national level during the Reformasi era, the state changed its legal orientation from promoting legal centralism to allowing more legal pluralism. It resulted, among others, of more than 500 regulations codified adat across Indonesian country, which were mostly directed to 
The Contemporary Changes ...

reclaim adat land rights (Arizona et al., 2017). The adat development in Aceh province was less concerned with the same attempt on adat land. It developed to similar way as the Minangkabau' adat where all public debates and expression were concentrated more on fitting the Nagari system into the ongoing agenda of nation-state building of Indonesia ( $\mathrm{F}$ \& K Benda-Beckmann, 2012). Adat in Aceh province was driven to the same route. It concerned more on nurturing local identity, developing legal and political aspects of adat to be part of the state.

The development of adat institution and law in Aceh province was supported by UNDP, in collaboration with the World Bank. Since 2007, both launched USD 7,9 million initiative to improve access to justice. The primary objective of the project was to build a stronger base for sustainable peace in Aceh in post conflict by supporting the ongoing development and assistance for the poor in securing their rights and improving their livelihood (UNDP, 2007).

Among important progress of the projects was the legalization of Qanun 9/2008 on the Supervision the Life of Adat and Adat Istiadat (customs) and Qanun 10/2008 on Adat Institution. The Qanun 9/2008 specifies eighteen minor cases that could be handled by adat institutions at the village. The Eighteen minor cases, as regulated in Article 13 of Qanun 9/2008 include: household quarrel, dispute among families regarding inheritance division, residential dispute, illicit relationship, dispute over property rights, theft in family or minor theft, dispute over joint property of husband and wife, theft of cattle or domesticated animals, offends of adat regulation on farms and forestry, fishery dispute, dispute in market, minor persecutions, small-scale of forest fire that harms an adat community, molestation, sedition, agitation, defamation, polluting environment in minor scale, threat (depending on the type), and lastly,

52| VOL. 10 NO. 1 JUNE 2021 
other disputes that offend adat law and costumes. The italic dispute is broad and vague that gives limitless authority for the adat institution to tackle any violation against local adat and customs.

Through the Qanun 10/2008, the Aceh government authorized traditional political institutions to tackle the eighteen minor cases detailed in Qanun 9/2008. The Qanun restores all traditional political territory, hierarchy and institutions of all ethnic groups in Aceh. Aside from making them as formal institutions in the village, the Qanun also designs autonomous institutions assisting the government in presenting public order. As an official alternative for the state legal system, adat institutions are allowed to, among other, solve communal issues, present peace to any occurring conflict within the society by enforcing the adat law (Article 3\&4 of Qanun 10/2008). According to Badruzzaman Ismail, head of Aceh Adat Council (MAA, Majelis Adat Aceh), designing adat or village institution for justice administration is to tackle the limits of the state legal system in developing public order.

Before enforcing the Qanun, MAA trained a large number of adat/village functionaries to run a new system adat judiciary. Supported by The World Bank, UNDP and BAPPENAS from 2007 to 2015, MAA trained 4,000 adat practitioners and village functionaries from all over Aceh provinces. Vernacularization and contextualization of universal and secular norms took place in the training. MAA instilled into the training the principles of human rights, women rights, Indonesia legal system, child protection, effective mediation, case handling, recording, and reporting dispute (UNDP, 2015). MAA also published a guideline for accessing and running adat judiciary to ensure that the adat institution serves justice, fairness, accountable (MAA, 2008). 
In Gayo, the adat elites and religious scholars also openly promoted the adat judiciary system and suggested people to bring their disputes to the adat institutions prior to the state courts. For example, Ali Jadun, head of local Ulama Consultative Board, said in one training on adat that:

“...bringing a dispute to adat, [either you] win or lose, you remain healthy. Would you bring the case to the state, even if you win, you lose half. Not to say if you lose, only bones remain [in you]..."

Ali Jadun described the different cost between bringing a case to adat and to state judicial systems. According to him, the adat process did not cost disputants, unlike the state court that cost a lot. To win a dispute in a court, someone should spend half of his wealth, let alone if someone lost in the courtroom, he could lose everything. From my observation in Kebayakan sub-district, the adat functionaries occasionally charged the disputants for their service for a low cost. Ichwan, a village secretary of Lot Kala village, said that the cost was to cover beverages for the meeting or to support reje and imem as the community occasionally wanted to have a private consultation in their homes.

\section{1) Qanun Kampong: Adat law for Social Transformation}

The village response to the development of adat penal law varies from one area to another, although the adat is now formalized and supported by the Aceh government. The response depends on the dominant actors and external power that influence the community. As a result, some adat becomes progressive and made relevant to the global idea of human rights, such as women and child rights protections, while some others become repressive toward the same ideas. 
In this section, I portray the progressive adat law by taking a case study from Rembele Village in Bener Meriah district. The community of the village consisted of roughly $60 \%$ of Gayonese and $40 \%$ of Javanese. The development of adat law was motored by Yusdarita and Hasanah Silang. Both were women activists that gradually developed themselves into prominent figures in advocating women and child issues in Bener Meriah district.

In two consecutive years $(2011 \& 2012)$ Aceh women activists noted that violence against women in Bener Meriah was the highest in Aceh Province (Uzia et al., 2013, p. 14). Yusdarita and Silang were among activists who were moved by the situation. They worked closely with the adat institutions. For them, working with the adat aimed at reforming the community. They started their social works from advocating victims of domestic violence. Gradually, they expanded their concern to victims of sexual harassment, and eventually they transformed and codified adat law of Rembele Village. They also designed the Rembele village to be "a safe village" for the victims of sexual harassment in Bener Meriah district.

The case of Rembele Village and the battle won by progressive social activists in Yusdarita and Hasanah Silang figures were good examples to show how adat became a battleground for actors who wanted to direct community to a particular form. They successfully facilitated the community to produce a pro-women and children adat and had it written to be Qanun Kampong (village regulation) for the first time.

The provision found in the village regulation was a mixture of Islamic, secular and adat norms. Secular tradition is seen in expanding the 
The Contemporary Changes ...

definition of domestic harassment that is not limited to physical harassment, but it includes economic, sexual and physiological harassments. The outcome describes the flexibility of adat to adjust to and accommodate external powers that stem from the global idea about human rights, child protection and other secular norms.

Yusdarita was a member of Women Volunteer for Humanities (RPuK, Relawan Perempuan untuk Kemanusiaan) founded in 1999 in Banda Aceh. Hasanah Silang was an inactive lawyer. When this research was conducted, she was part of local Independent Committee for Election (KIP, Komisi Independen Pemilihan) of Bener Meriah district. She was also part of nationwide legal assistance organization of Indonesian Women Association for Justice (APIK, Asosiasi Perempuan Indonesia untuk Keadilan).

Both Yusdarita and Silang often worked together voluntarily in advocating women and child need for justice. They were very well trained by some organizations concerning women and child issues from different perspectives. Their beliefs that social transformation should be started from the adat drove them to intensively cooperate with village leaders in dealing with women and child issues.

They passed through hard times, particularly Yusdarita. She was accused of being a witch and agent of American liberalism not only by adat practitioners who did not agree with her movement as she often challenged adat, but also by some women activists in the Bener Meriah district who thought that adat should be opposed due to its patriarchal nature where women and child misery sourced from. However, over the time, Yusdarita and Hasanah established their reputation as reliable socio-legal consultants, mediators, and women and child advocates in Bener Meriah district.

56| VOL. 10 NO. 1 JUNE 2021 
Yusdarita and Silang started their social works from advocating victims of domestic violence. They said that the most important part of the advocacy was the victim's condition after the violence. The court might solve the victim's problem and give protection by sending the husband to jail. But it was just a temporary solution. The husband would then sell all properties, including the house and the coffee plantation, which were generally registered under the husband's name. After that, the husband divorced his wife. The wife's life worsened as she must find a job to support her children. Such a situation often forced a wife to return to her husband although she had suffered and would suffer again.

To prevent bad situations for women and children, Yusdarita and Silang started appealing to an adat norm relating to compensation (tutup babah literarily means to hold the tongue). Traditionally, the tutup babah is not given for that has taken place, but for future violence; it needs to be written down and witnessed by many bystanders as a legal basis. It was meant to deliver a warning message to the husband. Yusdarita and Silang instead argued that the compensation should be given for the actual violence. To force the agreement, Silang explained to the village apparatuses and the perpetrator about Indonesian law related to domestic violence and the consequence of violating the law. Sometimes, they threatened the adat elites and village apparatus that they would expose the case to media, which could ruin the village's image. Such approaches were proven effective in making the village leaders change the adat practice that benefited the victim.

Challenging the tutup babah practice paved the way to empower women economically. During the negotiation, they forced husband to transfer ownership of some properties such as a portion of coffee plantation, 
house or any valuable goods like gold. According to them, domestic violence occurred because of, among other, the wife and children were economically dependents to the husband. These women did not have a financial security after divorce, compared to professional women such as civil servants. In a rural and agricultural society like in Bener Meriah, a husband controls all properties and decides the life of the entire family. The husband's power had to be limited by distributing ownership of valuable property to the wife. In case of dispute, Yusdarita and Silang often managed to affect this through the new tutup babah interpretation. Occasionally, Silang would report the case to the police to give more pressure to the husband and adat leaders. After they achieved their interests, they retreated the report, which is allowed within a certain period. According to them, this was effective not only because it prevents the husband to do another violence - as he might be forced to pay another compensation that would make him broke - but it also empower women economically which lead to the increasing wife's authority and autonomy in the household.

Gradually, Yusdarita and Hasanah expanded their concerns. Domestic violence was the only case that they could tolerate for being cooperative with adat institutions. For other cases, such as rape and pedophilia, they quickly made intervention and convince the adat leaders that the cases are beyond their authority and legal capacity. They then immediately involved the police into the case. Sometimes, in a pedophilia case I followed in 2007 (Serambi, 2017), they also involved adat leaders in searching for the victims in the village and controlling the impact of the case to the community.

Although they could convince the victims and adat leaders, sometimes the victims (women and girls) would be avoided by society. The victims 58| VOL. 10 NO. 1 JUNE 2021 
would be stigmatized as bad women or girls as they are considered to have provoked the crime. The situations inspired, in particular, Yusdarita to initiate a "safe village". In doing so, Yusdarita pushed her brothers, who acted as the head of the village and imam of the Rembele village at the time, to codify adat and issue a pro-women and child Qanun Kampong (village regulation). Convincing the village leaders, who had authority in the village, would ease her in converting the village into a "safe village" for the victims of sexual abuses.

This was not an easily process. Convincing brothers, who were influenced by and practicing patriarchal tradition, was challenging. She consulted with and learned about women and children issues from local ulama, among other were Ridwan Qari and Ali Jadun. Both scholars are highly respected among Ulama both in Central Aceh and Bener Meriah district. She found that Islam provides a wide array of arguments to confront against traditional patriarchal ideas. Moreover, the social class of the ulama as the most respected group are important to give another pressure to village elites. Yusdarita often brought their names into the debate with her brothers.

After more than five debates, she eventually succeeded at changing her brothers' perspective about gender and sexuality. In early 2010, she brought in a pregnant ex-prostitute to her village. Although Yusdarita's brothers supported the presence of the ex-prostitute, many village members protested as she might return to her old profession as a prostitute.

To change the community perspective, Yusdarita requested RPuK to facilitate a series of training on women and child issues for all the village 
The Contemporary Changes ...

functionaries including women. Funded by Unifem, which later turned to be UNWomen, RPuK held training in Banda Aceh and Bener Meriah district. The organization vernacularized and contextualized global idea such as human rights, women and child rights, national law on women and child, a pro-women Islamic perspective, husband and wife's role and responsibility in the family, and the adat mechanism in solving the communal issues as mandated by the Aceh and Indonesia government.

Among the outcomes of the training was the enactment of Qanun Kampong of Rembele village in the late 2010. It was the first Qanun Kampung postulated mechanism of solving the communal dispute, prevented the adat institution from tackling case related to crime such as rape, child abuse and major domestic violence. The Qanun also promoted gender equality in the adat institution and society as well as equal treatment between sons and daughters in a household. Islamic norms and Gayo adat were observed in Qanun Kampung in dealing with illegal sexual intercourse and the public morality, such as prohibiting a couple without marriage tie to be in a secluded place. This codified adat law also regulated punishment. For instance, parents who forced their daughter to an early marriage would be discriminated from the community and all their needs for the wedding and afterwards would not be assisted. Mutual assistance is crucial for the rural community. Losing such assistance would put them into uneasy situations.

In some parts of Aceh Province, adat also transformed from unwritten law nature, dominated by male and elderly to an organized and written law, accommodative toward women and children needs in accessing justice. The transformation was driven by the local organizations, Like RPuK and Center for Research and Education for Community (PKPM, Pusat Kajian dan Pendidikan Masyarakat), which are channeled to 60 | VOL. 10 NO. 1 JUNE 2021 
larger national and international organizations network such as UNWomen, USAID, AUSAID, UNDP, Restorative Justice Working Group, and UNICEF. The involvement of such organizations forced the vernacularization and contextualization of the global concept of rights to be applicable to a small locality of a village. Local actors, depending on the support or pressure from external forces and their capacity, would direct the adat to a certain form.

Like the family law, we have seen the development of adat penal law as a hybrid law that is sourced from and influenced by various ideology and norms such as Islam, local culture, international idea of equality, women and child rights. The adat law has been a field of contest for those who seek to direct the community to a certain situation. As portrayed in this essay, activists won the contest to bring the community to a progress situation. In other parts of Aceh, there are still, actors dominated the adat to repress women and child. In both progressive and repressive situations, actors vernacularize and contextualize the external elements into local contexts.

\section{Conclusion}

Since the early of $19^{\text {th }}$ to $21^{\text {st }}$ century, Gayonese, as well as other ethnic groups in Aceh province, passed through wars (against the Dutch and Japanese), conflicts (of Ulama revolt and Aceh Free Movement against Indonesia), and natural hazards (earthquakes and Tsunami). Aside from guns, soldiers, and humanitarian assistance, these occurrences brought civilians and organizations from different areas, cultures, norms, values and ideology to one area at once or simultaneously. They gradually inspired local people to adapt to the new encounters and situations by 
The Contemporary Changes ...

changing, among other subjects, their adat. Adat has been an instrument for social transformation. It is continuously (re)defined, (re)constructed, (re)organized to set a new standard of social life, a new way of looking at themselves and observing their actions and others, and a new way of maintaining internal stability and continuity. During the transformation, adat appeared to be a contested space of those from state and non-state as well as religious and secular actors and institutions to drive the society to a certain form of situation. The involvement and intervention of these actors made adat comprise many different ideology, norms and values derived from Islam, local culture, global ideas and secular ideologies. This constitutes adat law, as Benda-Beckmann describes, as hybrid law.

The incorporated external forces change the use of adat. On the family law aspect, adat is used now to maintain the continuity of kinship. They independently develop religious legal reasonings to meet the extended family's interest to maintain unity and harmony among them. The outcome may appear deviance to the standard Islamic law, in particular, to the science of inheritance division whose case was observed for this research. On the public order aspect, adat law is utilized by the state to support the legal enforcement in the community as well as to hasten the justice delivery to the community. Meanwhile, for the activists, the adat is functioned as a tool for communal transformation and serving the most vulnerable groups in the community such as women and children. During the process of the formulation, continuous intense debates take place on what ought to be and what not for adat becomes a contested field of those who carry the mission of communal transformation. 


\section{Endnotes}

i These two terms of kaum tue and mude seemingly appeared for the first time in Minangkabau the beginning of the 1900's. Kaum tue or tua in Minangkabau was a traditional group who unquestioned traditions, required student's obedience to the teachers and tended to be moderate, negotiating with adat and acknowledged individual ulama rights to produce ijtihad. In Minangkabau, this group was led for the first time by Ahmad Chatib (1860-1916). Meanwhile, kaum mude or muda is a group who sought reform and purification of Islam from unlawful religious practices in adat, condemned Sufism, used the Akal (intelligent) to practice Islam which in turn promoted the free will in producing ijtihad. This group was pioneered in Padang of West Sumatra by Sheikh H. A Karim Amrullah (Abdullah, 1970, pp. 2, 34, 64-66).

Both groups were also political. Kaum tua refused to cooperate with the colonial administration. While kaum muda tended to cooperate with authorities and promoted modernization in education. They developed a new method of teaching and curriculum that was a mixture of religious and secular lessons. This school was later known as modernized Madrasah that became a model for other Kaum Muda Schools (Abdullah, 1970, pp. 11, 41-42,48, 66). Large numbers of Minangkabau people who migrated to Gayo were likely part of the second group. Some of them worked at the Dutch schools, which showed their cooperation with the authority. Some other built their own schools modelling the Dutch's H.I.S schools.

${ }^{\text {ii }}$ During my fieldwork, I found that this classification is a knowledge of limited adat practitioners. There is also no standard definition for each classification. Different people gave a different explanation. In general, I draw explanations in a big picture as follows:

1. Adatullah is part of adat that is directly influenced or practicing religious teachings, such as marriage and death rituals. In principle, the adat is expected to be in line with Islamic teachings.

2. Adat Muhakamah is an adat aspect that has legal consequences or adat law. According to Yusen Saleh and Mahmud Ibrahim, this adat is produced through a public consensus. Because community maintains the agreement, it gradually becomes a custom then becomes part of adat law. Those who act against the agreement would face certain punishment such as an exclusion from the community.

3. Adat Mutmainnah is a good practice in adat that is not inspired from Islam nor does it against Islamic teachings. It is considered as an innovation that does not promote practices against the tenets of Islam, for example the prohibition of endogamous marriage. According to Mahmud Ibrahim and other adat practitioners, although Islam allows its believers to marry with their own community members, Gayonese

HERITAGE OF NUSANTARA: INTERNATIONAL JOURNAL OF RELIGIOUS LITERATURE AND HERITAGE 
prefer to prohibit such practice from preventing internal conflict among the community members.

4. Adat Jahilayah is part of the adat that opposes Islamic tenets, values, and norms. For example, according to Yusen Saleh, is dancing during the wedding, gambling, and cockfighting.

5. The last is resam. Resam is a tradition which is not practiced by all Gayonese. It is a specific habit, customs or regulation made and agreed by a specific community or village or a group of people in the community. According to many local adat practitioners, resam is the actual living adat that is practiced differently from one village to another, although there are also similarities as they are inspired from the general concept of Gayo adat.

\section{References}

Abdullah, T. (1970). Schools and Politics: The "Kaum Muda" Movement in West Sumatra (1927-1933) [Cornell University]. http://search.proquest.com/docview/302519029/

Aktual. (2015, October 10). Polri Usulkan Hukum Adat Masuk RUU KUHP - Aktual.Com Terhangat Terpercaya. Terhangat Terpercaya. http://www.aktual.com/polri-usulkan-hukum-adatmasuk-ruu-kuhp/

Arizona, Y., Malik, \& Ishimora, I. L. (2017). Pengakuan Hukum terhadap Masyarakat Adat: Tren Produk Hukum Daerah dan Nasional Pasca Putusan MK 35/PUU-X/201 (Outlook Epistima 2017).

Epistema

Insitute. http://epistema.or.id/publikasi/publikasi-berkala/outlookepistema-2017/

Aziz, A. (2016, October 3). RUU KUHP Akan Akomodir Hukum Adat. Tirto.Id. https://tirto.id/ruu-kuhp-akan-akomodir-hukum-adathH7

Bedner, A. W., \& Arizona, Y. (2019). Adat in Indonesian Land Law: A Promise for the Future or a Dead End? The Asia Pacific Journal of Anthropology, 20(5), 416-434.

Bedner, A. W., \& Huis, S. C. V. (2008). The Return of the Native in Indonesian Law. Bijdragen Tot de Taal-, 164(2/3), 165-193. 
Benda-Beckmann, F. V., \& Benda-Beckmann, K. V. (2012). Identity in dispute: Law, religion, and identity in Minangkabau. Asian Ethnicity, 13(4), 341-358.

Benda-Beckmann, F. V., \& Benda-Beckmann, K. V. (2013). Decentralisation, the transformation of the nagari and the dynamics of legal pluralism. Cambridge: Cambridge University Press.

Bouchier, D. (2007). The romance of adat in the indonesian political imagination and the current revival. In J. S. Davidson \& D. Henley (Eds.), The revival of tradition in Indonesian politics: The deployment of adat from colonialism to indigenism. Routledge.

Bowen, J. R. (1988). The Transformation of an Indonesian Property System: "Adat," Islam, and Social Change in the Gayo Highlands. American Ethnologist, 15(2), 274-293.

Bowen, J. R. (1991). Sumatran politics and poetics: Gayo history, 19001989. Yale University Press.

Bowen, J. R. (1998). "You May Not Give It Away": How Social Norms Shape Islamic Law in Contemporary Indonesian Jurisprudence. Islamic Law and Society, 5(3), 382-408.

Bowen, J. R. (2000). Consensus and suspicion: Judicial reasoning and social change in an Indonesian society 1960-1994. Law \& Society Review, 34(1), 97-127.

Bowen, J. R. (2003). Islam, law, and equality in Indonesia: An anthropology of public reasoning. Cambridge University Press.

Erb, J. S. (2007). Adat Revivalism in Western Florest: Culture, Religion and Land. In J. S. Davidson \& D. Henley (Eds.), The revival of tradition in Indonesian politics: The deployment of adat from colonialism to indigenism. Routledge.

Ibrahim, M., \& Pinan, A. R. H. A. (2002). Syari'at dan Adat Istiadat (1st ed., Vol. 1). Yayasan Maqamammahmuda.

Ibrahim, M., \& Pinan, A. R. H. A. (2005). Syari'at dan Adat Istiadat (1st ed., Vol. 3). Yayasan Maqamammahmuda. 
Ibrahim, M., \& Pinan, A. R. H. A. (2010). Syari'at dan Adat Istiadat (4th ed., Vol. 2). Yayasan Maqamammahmuda.

MAA. (2008). Guidelines on Adat Justice in Aceh For Adat Justice that is Fair and Accountable. Aceh Adat Council. http://www.undp.org/content/dam/indonesia/docs/Buku_Adat_A ceh_-_Eng_Version_V_-_HQ.pdf

Muur, W. van der. (2018). Forest conflicts and the informal nature of realizing indigenous land rights in Indonesia. Citizenship Studies, 22(2), 160-174.

Muur, W. van der, Vel, J., Fisher, M. R., \& Robinson, K. (2019). Changing Indigeneity Politics in Indonesia: From Revival to Projects. The Asia Pacific Journal of Anthropology, 20(5), 379396.

PaEni, M. (2003). Riak di laut tawar: Kelanjutan tradisi dalam perubahan sosial di Gayo-Aceh Tengah (Cet. 1..). Arsip Nasional Republik Indonesia.

Pinan, A. R. H. A. (1997). Pelestarian Budaya Tradisional Masyarakat Pendukungnya. Unpublished.

Pinan, A. R. H. A. (2003). Pesona Tanoh Gayo (Nasaruddin \& Aqli H, Eds.). Pemerintah Kabupaten Aceh Tengah.

Serambi, I. (2017, November 15). Tersangka Pedofil Mulai Diadili [News]. Serambi Indonesia. http://aceh.tribunnews.com/2017/11/15/tersangka-pedofil-mulaidiadili

Shahrur, M. (2004). Metodologi Fiqih Islam Komtemporer (S. Syamsuddin, Ed.; S. Syamsuddin \& Burhanuddin, Trans.). Elsaqpress.

UNDP. (2007). UNDP and World Bank Launch USD 7.9 million Initiatives to Improve Access to Justice in Aceh. UNDP in Indonesia.

http://www.undp.org/content/indonesia/en/home/presscenter/tsu nami-in-aceh/undp-and-world-bank-launch-usd-7-9-millioninitiatives-to-improv.html

UNDP. (2015). Public lecture by UNDP Indonesia Country Director Christophe Bahuet on Access to Justice and Global Development 
Goals at University of Syiah Kuala, Banda Aceh. UNDP in Indonesia.

http://www.undp.org/content/indonesia/en/home/presscenter/speeches/ 2015/12/01/public-lecture-by-undp-indonesia-country-directorchristophe-bahuet-on-access-to-justice-and-global-developmentgoals-at-university-of-syiah-kuala-banda-aceh.html

Uzia, A., Rambe, A., Lestari, D. G., \& Zahara, E. (2013). Menjelujur Pengalaman Kekerasan Perempuan di Aceh: Perjuangan Tiada Henti Meniti Keadilan: Catatan Dua Tahun Terakhir, 2011-2012 Kekerasan Terhadap Perempuan di Aceh. https://www.komnasperempuan.go.id/file/pdf_file/2018/Publika si/Catatan\%20Dua\%20Tahun\%20Terkahir\%20(20112012)\%20Kekerasan\%20Terhadap\%20Perempuan\%20di\%20Ac eh.pdf 